\title{
ANALISIS FINANSIAL DAN NILAI TAMBAH USAHA AGROFORESTRI KOPI PADA PROGRAM CSR PT INDONESIA POWER UP MRICA KABUPATEN BANJARNEGARA
}

\author{
Faradis Alfi Zain ${ }^{1 *}$, Dodik Ridho Nurrochmat ${ }^{2}$ \\ ${ }^{1}$ Program Studi Manajemen Hutan, Fakultas Kehutanan, \\ Institut Pertanian Bogor (IPB), Bogor 16680 \\ 2 Departemen Manajemen Hutan, Fakultas Kehutanan, \\ Institut Pertanian Bogor (IPB), Bogor 16680 \\ *Email: faradis22alfi@gmail.com
}

\section{RINGKASAN}

Kegiatan pembudidayaan sayuran di wilayah hulu menjadi faktor utama penyumbang sedimentasi Waduk Panglima Besar Soedirman. Penanaman komoditas kopi melalui program Sekolah Lapang Konservasi dimaksudkan sebagai salah satu alternatif guna membenahi permasalahan ini. Tujuan dari penelitian ini adalah menganalis kelayakan finansial usaha kopi pada berbagai pola agroforestri, menguji tingkat sensitivitas dari penurunan harga dan kenaikan biaya input terhadap keuntungan usaha, serta besaran nilai tambah dari setiap bentuk olahan buah kopi di Desa Leksana, Kecamatan Karangkobar, Kabupaten Banjarnegara. Berdasarkan perhitungan analisis finansial yang dilakukan menggunakan metode Discounted Cash Flow, usaha dengan pola agroforestri jambu, sengon, kopi arabika lebih menguntungkan dibandingkan pola agroforestri sengon, kopi robusta dan pola agroforestri sengon, kopi robusta pagar. Usaha agroforestri kopi di Desa Leksana lebih sensitif terhadap penurunan harga jual daripada kenaikan biaya produksi. Menurut perhitungan nilai tambah menggunakan metode Hayami, olahan produk kopi pada level roasted bean memberikan nilai tambah yang terbesar dibandingkan dengan produk olahan lainnya.

Kata kunci: agroforestri, analisis finansial, kopi, nilai tambah

\section{PERNYATAAN KUNCI}

- $\quad$ Peningkatan jumlah komoditas yang didominasi sayuran berdampak positif terhadap peningkatan nilai ekonomi masyarakat. Namun peningkatan jumlah komoditas sayuran tanpa diimbangi oleh tanaman keras akan berdampak negatif terhadap aspek ekologi di wilayah pegunungan.

- Masyarakat mulai menanam kopi secara masif sejak dimulainya program Sekolah Lapang Konservasi melalui kerjasama PT Indonesia Power UP Mrica dan Dinhutbun 
Kabupaten Banjarnegara pada tahun 2009.

- Motivasi masyarakat menanam kopi adalah untuk upaya konservasi tanah dan air serta menjadikannya sebagai usaha sampingan karena dalam pelaksanaannya tidak membutuhkan modal banyak.

- Tingginya permintaan kopi dalam periode waktu yang singkat berpotensi mengurangi persediaan kopi secara drastis. Hal ini dapat mempengaruhi kontinuitas penjualan kopi, sehingga kajian mengenai strategi pemasaran perlu dilakukan.

\section{REKOMENDASI KEBIJAKAN}

- Penanaman kopi memberikan manfaat ekonomi yang tinggi bagi masyarakat, sehingga perlu dikembangkan lagi pengelolaannya agar dapat berproduksi secara optimal.

- Beberapa alternatif untuk mengoptimasi lahan petani di Desa Leksana adalah dengan memperbaiki pola tanam dan menanam tanaman MPTS (Multipurpose Tree Species) yang toleran terhadap naungan.

- Memberikan edukasi pada petani tentang selecting and grading biji kopi. Agar biji yang berkualitas specialty cukup diolah sampai produk green bean dan roasted bean, sedangkan biji yang berkualitas di bawahnya diolah hingga menjadi bubuk kopi, sehingga keuntungan yang diperoleh akan lebih optimal.

\section{PENDAHULUAN}

Sub DAS Merawu merupakan salah satu Sub DAS kritis di Banjarnegara karena memiliki pola sedimentasi yang terus meningkat dan laju erosi yang sangat fluktuatif setiap tahunnya. Tercatat pada tahun 2009, tingkat laju erosi di Sub DAS Merawu mencapai 13,30 mm (Indonesia Power, 2018). Sebagian besar masyarakat di daerah hulu Waduk Panglima Besar Soedirman hanya berfokus pada pembudidayaan sayuran. Pola tanam yang kurang beraturan sangat bervariasi mengikuti tren yang sedang berlangsung dan kondisi ekonomi setiap petani, serta kurangnya tanaman keras yang ditanam mengakibatkan fungsi hidrologi di daerah pegunungan terus berkurang. Oleh sebab itu tutupan lahan bervegetasi pada bagian hulu Waduk PB Soedirman sangat diperlukan guna mengurangi laju erosi dan sedimentasi.

Salah satu alternatif dalam membenahi permasalahan ini adalah dengan menerapkan pola tanam agroforestri. Darusman (2002) dalam Hairiah et al, (2003) mengungkapkan bahwa sistem agroforestri memiliki lebih banyak keunggulan dibandingkan sistem yang lain, yaitu terciptanya kestabilan ekologi yang lebih tinggi, terciptanya kesinambungan ekonomi 
yang berimbas pada peningkatan kesejahteraan petani, tingkat kesesuaian yang lebih tinggi dengan budaya dan pengetahuan petani, serta terpenuhinya kestabilan politik akibat daya terima yang lebih luas di masyarakat.

Awal tahun 2009 Dinas Kehutanan dan Perkebunan Kabupaten Banjarnegara bersama PT Indonesia Power UP Mrica menginisiasi diselenggarakannya program guna menyadarkan masyarakat lokal mengenai pentingnya usaha pemeliharaan kawasan hulu yang diberi nama program Sekolah Lapang Konservasi (SL Konservasi). Penentuan objek CSR didasarkan oleh pemetaan kawasan Sub DAS yang paling banyak memberikan kontribusi sedimentasi, yakni Sub DAS Merawu, yang terletak di Desa Leksana, Kecamatan Karangkobar dan Desa Kubang, Kecamatan Wanayasa.

Komoditas yang dijadikan sebagai objek pada program SL Konservasi ini adalah kopi. Kopi telah menjadi produk andalan penyumbang devisa negara karena besarnya permintaan pasar global terhadap komoditas ini. Dalam penelitian yang dilakukan Sudjarmoko (2013), disebutkan bahwa ekspor kopi Indonesia yang cenderung fluktuatif masih didominasi oleh ekspor biji kopi sebesar 99.8 persen dan sisanya dalam bentuk bubuk. Sebagai salah satu negara eksportir kopi dunia, produksi kopi menjadi input utama dalam kegiatan ekspor negara Indonesia. Dalam program SL Konservasi, pembudidayan kopi direkomendasikan sebagai alternatif pemanfaatan lahan di daerah pegunungan karena perakarannya yang kuat dan bersifat toleran terhadap naungan. Penerapan pola agroforestri kopi tidak hanya memiliki nilai konservasi, ekologi, sosial budaya, namun jika dikelola dengan teknologi yang tepat akan memberikan nilai ekonomi yang signifikan.

Adanya pengetahuan mengenai hasil analisis finansial akan membantu petani dalam mengalokasikan sumberdaya yang dimiliki untuk memperoleh keuntungan pada selang waktu tertentu secara efektif dan efisien. Disamping itu, mengingat bahwa hampir $99.8 \%$ buah kopi dieskpor dalam bentuk biji, maka pengetahuan mengenai besaran nilai tambah dari setiap bentuk olahan kopi juga diperlukan sebagai alternatif bagi para petani dalam menjual produknya.

\section{SITUASI TERKINI}

\section{Pola Tanam Kopi di Desa Leksana}

Jenis kopi yang dicanangkan pada program SL Konservasi adalah jenis kopi robusta, karena memiliki perakaran yang lebih kuat dan mampu menghasilkan buah per tanaman yang lebih banyak dibanding jenis arabika, meskipun nilai jualnya lebih rendah. Saat dimulainya kegiatan penanaman SL Konservasi, petani menyediakan hampir setengah dari 
kepemilikan lahannya untuk ditanami kopi.

Dari total lahan garapan seluas 20,87 ha, 9,16 ha diantaranya ditargetkan untuk ditanam komoditi kopi. Secara umum pola tanam kopi di Desa Leksana terbagi menjadi 2 macam.
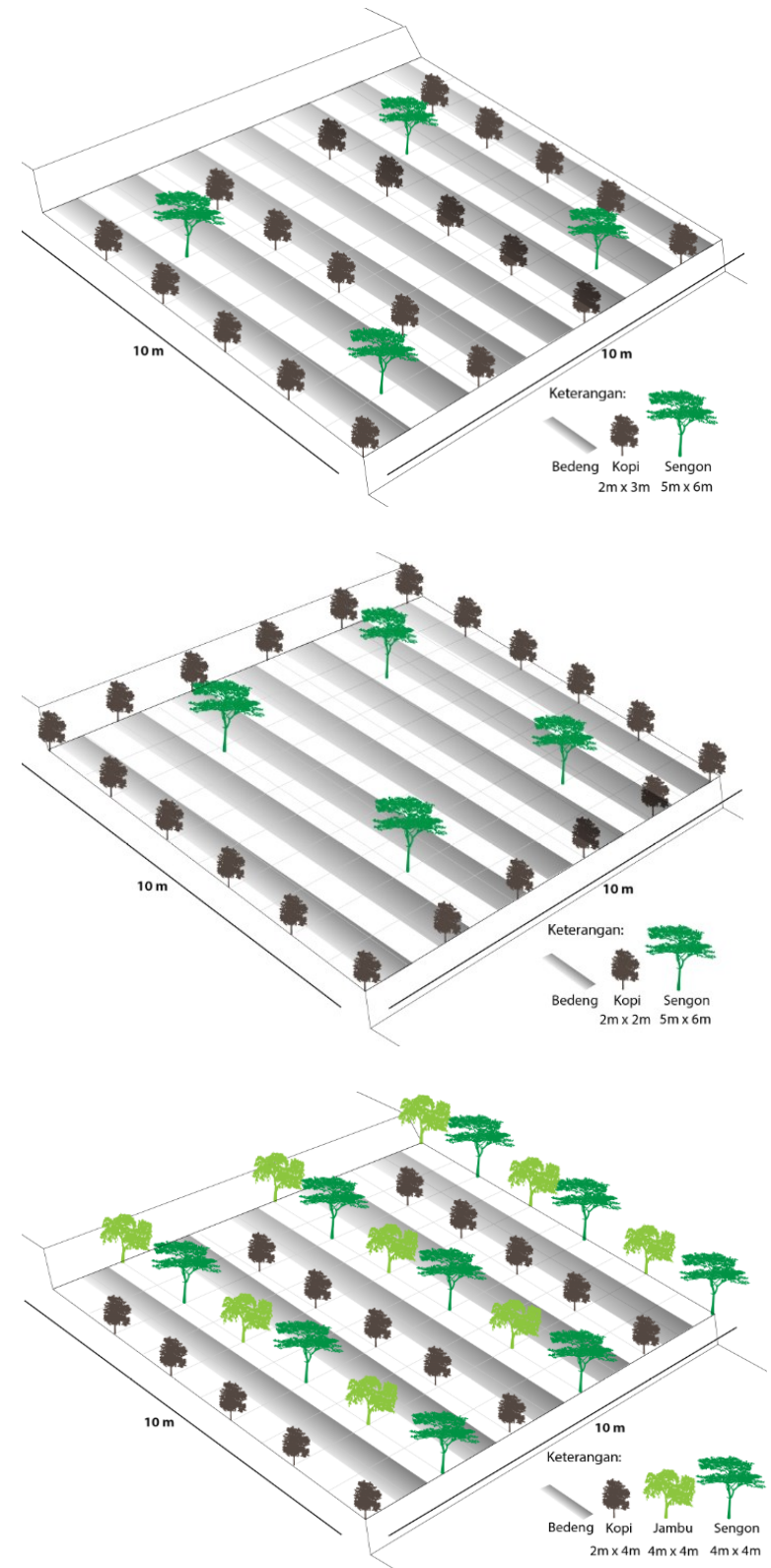

Gambar 1 Pola tanam agroforestri sengon kopi robusta (I), agroforestri sengon kopi robusta pagar (II), agroforestri jambu sengon kopi arabika (III)

Pola pertama (I) adalah penanaman kopi robusta secara menyeluruh di setiap sela bedeng sayuran dengan jarak $2 \mathrm{~m}$ x $3 \mathrm{~m}$ ditambah selingan sengon pada setiap jarak 5-6 m, sehingga diproyeksikan pada tahun kedua dan seterusnya bidang lahan tersebut terpenuhi oleh kopi dan sengon. Sayuran hanya mampu tumbuh optimal hingga umur 2 tahun, karena di tahun tersebut cabang kopi sudah mulai rapat menaungi tanah di bawahnya.

Pola kedua (II) yang umum dijumpai di lokasi penelitian adalah penanaman kopi robusta yang hanya ditanam di sekeliling lahan petani sebagai tanaman pagar dengan jarak tanam $2 \mathrm{~m}$, dan di sela bedengan hanya ditanami sengon setiap 5-6 $\mathrm{m}$, sehingga sayuran masih mampu tumbuh optimal sampai jangka waktu pengusahaan berakhir. Pada penelitian ini dibuat sebuah pola simulasi (III) yakni dengan tetap menanam sengon dan menambahkan tanaman jambu kristal, serta mengganti kopi robusta dengan jenis arabika yang memiliki nilai toleransi lebih tinggi terhadap naungan. Jambu dan sengon ditanam secara selang-seling dengan jarak tanam $4 \mathrm{~m} \times 4 \mathrm{~m}$, sedangkan kopi arabika pada sela bedengan di sampingnya dengan jarak tanam $2 \mathrm{~m}$ x $4 \mathrm{~m}$. Pembuatan pola III dimaksudkan untuk membandingkan apakah secara ekonomi sistem agrokompleks ini mampu mengimbangi atau bahkan melebihi sistem hortikultura konvensional yang telah lama diterapkan oleh para petani (pola II).

\section{Penerimaan dan Biaya Usaha}


Pada Kelompok Sari Tani, ketua kelompok yang berinisiatif untuk membeli hasil panen buah kopi langsung dari para anggota kelompok, sehingga harganya cenderung stabil. Dengan adanya bantuan alat dari PT Indonesia Power, petani sangat terfasilitasi untuk menjual produk kopinya secara mandiri, mulai dari bentuk green bean, roasted bean, maupun bubuk kopi. Ketua kelompok membeli buah kopi robusta dari para petani per kilonya seharga $\mathrm{Rp} 5.500$,- dan kopi arabika Rp 7.000,-. Besar penerimaan yang digunakan dalam perhitungan analisis finansial ini hanya harga buah kopi, tidak sampai pada harga olahan green bean dan roasted bean, karena semua anggota kelompok tani hanya memperoleh penerimaan dari buah kopi. Harga jual kopi jenis robusta dan arabika serta olahannya di Desa Leksana dapat dilihat pada Tabel 1 .

Tabel 1. Harga jual kopi robusta dan arabika di Desa Leksana

\begin{tabular}{llrc}
\hline \multirow{2}{*}{ No. } & Jenis & Robusta & Harga $(\mathrm{Rp} / \mathrm{kg})$ \\
\cline { 3 - 4 } & & 5.500 & Arabika \\
\hline 1 & Buah (Cherry) & 40.000 & 7.000 \\
2 & Green Bean & 125.000 & 100.000 \\
3 & Roasted Bean & 150.000 & 250.000 \\
4 & Bubuk Kopi & & 300.000 \\
\hline
\end{tabular}

Tabel 2. Total aliran kas masuk pada pola agroforestri kopi di Desa Leksana

\begin{tabular}{|c|c|c|c|c|c|}
\hline \multirow{2}{*}{$\begin{array}{c}\text { Pola } \\
\text { Agroforestri }\end{array}$} & \multicolumn{4}{|c|}{ Jumlah (Rp/ha) } & \multirow{2}{*}{$\begin{array}{c}\text { Total } \\
\text { (Rp/ha) }\end{array}$} \\
\hline & Sayuran & Kopi & Sengon & Jambu & \\
\hline $\begin{array}{l}\text { sengon \& } \\
\text { kopi robusta }\end{array}$ & 757.436 .400 & 325.662 .375 & 273.600 .000 & - & 1.356 .698 .775 \\
\hline $\begin{array}{l}\text { sengon \& } \\
\text { kopi robusta } \\
\text { pagar }\end{array}$ & 5.713 .394 .400 & 136.386 .750 & 273.600 .000 & - & 6.123 .381 .150 \\
\hline $\begin{array}{l}\text { jambu, } \\
\text { sengon, \& } \\
\text { kopi arabika }\end{array}$ & 577.656 .000 & 267.710 .950 & 641.250 .000 & 1.638 .451 .200 & 3.125 .068 .150 \\
\hline
\end{tabular}


Pemasukan lain yang diterima petani adalah penjualan kayu sengon dan buah jambu kristal. Kayu sengon sebetulnya dijual oleh petani saat diperlukan pemasukan lebih sesuai desakan kebutuhan, atau biasa disebut tebang butuh. Karena volume kayu yang dihasilkan cukup bervariasi akibat perbedaan bibit dan sistem pemeliharaan, maka harga sengon diasumsikan sama yakni sebesar Rp 300.000,- sesuai dengan harga minimum sengon yang memiliki lingkar $70-80 \mathrm{~cm}$ $(\mathrm{d}=25 \mathrm{~cm})$ di Kecamatan Karangkobar. Umumnya pada umur 5 tahun sengon dapat mencapai ukuran diameter tersebut dan diperkirakan harganya akan terus meningkat.

Tanaman jambu kristal yang dibudidayakan oleh petani di Desa Leksana mampu menghasilkan buah pada tahun pertama dan kedua setiap minggunya ratarata sebanyak 0,5 kg, tahun ketiga dan keempat sebesar 1,05 kg per tanaman, dan diperkirakan akan terus meningkat hingga mencapai puncak produktivitas di umur 6 dan 7 tahun. Rincian total pemasukan dari setiap komoditas yang diusahakan pada pola agroforestri kopi di Desa Leksana ditampilkan pada Tabel 2.

Jika dibandingkan antara ketiga pola, pengeluaran pada pola II dan III memiliki tingkat pembiayaan yang jauh lebih besar yaitu pada biaya variabel, dari mulai penyediaan bibit hingga pemanenan. Hal ini disebabkan karena pada pola II sayuran mampu ditanam hingga jangka waktu pengusahaan berakhir, maka selalu ada pengeluaran di setiap tahunnya. Sementara pada pola III terdapat tambahan komoditas jambu yang membuat biaya pemeliharaannya meningkat tajam.

\section{ANALISIS DAN ALTERNATIF SOLUSI}

\section{Analisis Finansial Usaha Agroforestri Kopi Desa Leksana}

Kelayakan usaha dihitung dalam jangka waktu pengusahaan selama 15 tahun dengan luasan sama setiap polanya, yakni 1 hektar. Selama jangka waktu pengusahaan, tanaman kopi diasumsikan 1 kali daur yakni sesuai umur produktifnya, sengon diasumsikan 3 kali daur yang berarti dipanen setiap berumur 5 tahun, dan jambu diasumsikan 2 kali daur yaitu setelah tanaman jambu berumur 10 tahun. Analisis finansial dilakukan dengan melihat rekapitulasi arus masuk dan arus keluar kas yang dibuat dalam suatu cash flow dalam masing-masing unit usaha. Sementara hasil perhitungan terhadap analisis finansial pada sistem agroforestri pola-I (sengon dan kopi robusta), pola-II (sengon dan kopi robusta pagar), dan pola-III (jambu, sengon, dan kopi arabika) ditampilkan dalam Tabel 3. 
Tabel 3. Rekapitulasi cashflow pada sistem pengelolaan agroforestri pola-I, pola-II, dan pola-III di Desa Leksana

\begin{tabular}{lrrr}
\hline $\begin{array}{c}\text { Kriteria } \\
\text { Kelayakan } \\
\text { Investasi }\end{array}$ & $\begin{array}{c}\text { Pola-I } \\
\text { (Sengon dan } \\
\text { Kopi Robusta) }\end{array}$ & $\begin{array}{c}\text { Pola-II } \\
\text { (Sengon dan Kopi } \\
\text { Robusta Pagar) }\end{array}$ & $\begin{array}{c}\text { Pola-III } \\
\text { (Jambu, Sengon, } \\
\text { dan Kopi Arabika) }\end{array}$ \\
\hline $\mathrm{NPV} \mathrm{(Rp/ha/15tahun)}$ & 469.422 .559 & 1.286 .677 .768 & 1.315 .264 .047 \\
$\mathrm{BCR}$ & 1,74 & 1,44 & 2,41 \\
$\mathrm{IRR}$ & $95 \%$ & $106 \%$ & $113 \%$ \\
\hline
\end{tabular}

Berdasarkan Tabel 3, pola III memiliki nilai NPV yang terbesar dibandingkan kedua pola lainnya. Pola ketiga merupakan pola simulasi dengan tambahan komoditas dari MPTS yakni tanaman jambu kristal, atau dapat disebut dengan sistem agrokompleks. Selama jangka waktu pengusahaan 15 tahun petani pada pola ketiga akan memperoleh manfaat bersih sebanyak Rp 1.315.264.047,-/ha. Angka ini tentu cukup menjanjikan karena mampu menandingi sistem hortikultura konvensional (pola II) yang telah lama diterapkan sebelumnya oleh para petani. Selain memberikan nilai NPV lebih besar, sistem pemeliharaan pada pengelolaan pola ketiga juga lebih sederhana dibandingkan pola kedua.

Semua sistem pengelolaan yang diterapkan pada ketiga pola memiliki nilai BCR lebih dari satu, maka proyek pada setiap pola tersebut dinilai layak dan menguntungkan untuk dijalankan. Diketahui sistem pengelolaan pada setiap pola menggunakan suku bunga deposito Bank BRI sebesar 5\%. Diantara ketiga pola yang diusahakan, pola ketiga (simulasi) memiliki nilai BCR yang terbesar yaitu 2,41\%. Hal ini terjadi karena pendapatan terdiskonto yang diperoleh pola ketiga jauh lebih besar dibandingkan ketiga pola lainnya.

Nilai IRR yang dihasilkan dapat menggambarkan besarnya kemampuan usaha untuk mengembalikan modal yang dikeluarkan. Ketiga pola pengusahaan sesuai dengan Tabel 3 memiliki nilai IRR yang lebih dari sama dengan tingkat suku bunga deposito 5\%, maka ketiga proyek tersebut layak untuk diusahakan dan terus dikembangkan. Pola III memiliki tingkat IRR tertinggi yakni sebesar 113\%, sedangkan pola II dan III memiliki tingkat IRR senilai 95\% dan 106\%.

Nilai IRR yang dihasilkan oleh ketiga pola sangat besar disebabkan karena usahatani ini selalu mendapatkan pemasukan setiap tahun yang dapat mengkover keseluruhan biaya pada tahun tersebut. Oleh sebab itu tingkat pengembaliannya cepat hingga mencapai 100\%. Namun IRR bukanlah metrik yang dapat diandalkan untuk membuat suatu keputusan, karena suatu usaha yang 
memiliki nilai tingkat pengembalian internal (IRR) tinggi tidak selalu lebih baik dibandingkan usaha yang memiliki nilai IRR rendah (Gittinger, 2008). Proyek yang baik tetap merupakan proyek yang memberikan lebih banyak hasil kepada pendapatan dibandingkan terhadap sumberdaya yang digunakan.

Tabel 4. Hasil analisis sensitivitas usaha agroforestri kopi di Desa Leksana

\begin{tabular}{|c|c|c|c|c|c|c|}
\hline \multirow[b]{2}{*}{ Uraian } & \multirow[b]{2}{*}{ Pola Agroforestri } & \multicolumn{3}{|c|}{ Kondisi } & \multicolumn{2}{|c|}{$\begin{array}{c}\text { Persen } \\
\text { perubahan }\end{array}$} \\
\hline & & Normal & $\begin{array}{c}\text { Harga turun } \\
10 \%\end{array}$ & $\begin{array}{c}\text { Biaya naik } \\
10 \%\end{array}$ & $\begin{array}{l}\text { Harga } \\
\text { turun } \\
10 \%\end{array}$ & $\begin{array}{l}\text { Biaya } \\
\text { naik } \\
10 \%\end{array}$ \\
\hline \multirow{3}{*}{$\begin{array}{l}\text { NPV } \\
\text { (Rp) }\end{array}$} & Kopi sengon & 469.422 .559 & 358.723 .563 & 405.665 .819 & 23,58 & 13,58 \\
\hline & Kopi sengon pagar & 1.286 .677 .768 & 863.233 .874 & 991.901 .650 & 32,91 & 22,91 \\
\hline & $\begin{array}{l}\text { Kopi sengon } \\
\text { jambu }\end{array}$ & 1.315 .264 .047 & 1.090.328.359 & 1.221 .854 .764 & 17,10 & 7,10 \\
\hline \multirow{3}{*}{$\begin{array}{l}\text { IRR } \\
(\%)\end{array}$} & Kopi sengon & 95 & 65 & 67 & 31,58 & 29,47 \\
\hline & Kopi sengon pagar & 106 & 72 & 75 & 32,08 & 29,25 \\
\hline & $\begin{array}{l}\text { Kopi sengon } \\
\text { jambu }\end{array}$ & 113 & 88 & 90 & 22,12 & 20,35 \\
\hline \multirow{3}{*}{ BCR } & Kopi sengon & 1,74 & 1,56 & 1,58 & 10,34 & 9,20 \\
\hline & Kopi sengon pagar & 1,44 & 1,29 & 1,31 & 10,42 & 9,03 \\
\hline & $\begin{array}{l}\text { Kopi sengon } \\
\text { jambu }\end{array}$ & 2,41 & 2,17 & 2,19 & 9,96 & 9,13 \\
\hline
\end{tabular}

\section{Analisis Sensitivitas Usaha Agroforestri Kopi Desa Leksana}

Analisis sensitivitas diterapkan untuk menilai hal-hal yang akan terjadi terhadap hasil analisis kelayakan suatu proyek apabila terjadi perubahan di dalam perhitungan biaya atau manfaat. Menurut Nurmalina et al, (2010) perubahan yang sering terjadi dalam menjalankan bisnis adalah perubahan harga, keterlambatan pelaksanaan, kenaikan biaya, dan perubahan hasil produksi. Analisis sensitivitas pada penelitian ini dilakukan dengan dua skenario yaitu apabila terjadi penurunan penjualan kopi, sayuran, dan buah jambu kristal sebesar 10\%, dan apabila terjadi kenaikan biaya total dalam pengelolaan usaha sebesar 10\%. Hasil analisis sensitivitas usaha agroforestri kopi ditunjukkan oleh Tabel 4.

Berdasarkan hasil analisis sensitivitas pada Tabel 4, meskipun terjadi perubahan terhadap nilai NPV, IRR serta BCR, tetapi secara umum kondisi kelayakan usaha tidak mengalami perubahan pada kenaikan biaya atau penurunan penerimaan sebesar $10 \%$. Nilai NPV yang dihasilkan masih lebih besar dari 0, nilai BCR masih lebih besar dari 1 dan nilai IRR yang dihasilkan masih lebih besar dari tingkat suku bunga yang digunakan yaitu 5\%. Perbandingan persentase perubahan nilai ketiga kriteria yang digunakan menunjukkan penurunan 
harga produk sebesar 10\% menghasilkan perubahan negatif yang lebih besar daripada terjadinya kenaikan biaya input sebesar $10 \%$. Artinya usaha agroforestri kopi di Desa Leksana akan lebih sensitif terhadap faktor-faktor yang mempengaruhi terjadinya penurunan harga jual produk dibandingkan hal-hal yang berpengaruh terhadap kenaikan biaya modal.

\section{Analisis Nilai Tambah Produk Olahan Kopi}

Kondisi saat ini di lapangan menunjukkan bahwa petani adalah agen ekonomi yang memperoleh keuntungan terkecil dan menanggung risiko produksi tertinggi. Oleh karena itu, pengembangan agroindustri dapat digunakan sebagai model alternatif pemberdayaan masyarakat untuk meningkatkan nilai tambah produk dengan memanfaatkan bahan baku lokal. Meskipun skala bisnis ini masih dikategorikan sebagai industri skala rumah tangga, produk yang dihasilkan akan mampu memperkaya variasi produk di pasar lokal dan mengisi pasar di luar wilayah (Aklimawati et al, 2016). Menurut Hayami et al, (1987), nilai tambah merupakan penambahan nilai pada input dengan melakukan proses pengangkutan, pengolahan, dan penyimpanan dalam suatu produksi sehingga menghasilkan output yang bernilai lebih tinggi dibandingkan dengan input.

Perhitungan nilai tambah dilakukan pada setiap bentuk olahan buah kopi, yaitu green bean, roasted bean, dan bubuk kopi, baik jenis robusta maupun arabika. Output dan input yang digunakan serta dihasilkan berbeda setiap produknya. Hal ini karena penyediaan bahan baku dan kapasitas produksi yang berbeda di setiap pengolahannya. Jadi penentuan bahan baku sejumlah $100 \mathrm{~kg}$ hanya berlaku untuk buah kopinya saja, bahan baku green bean dan roasted bean akan menyesuakan dengan seberapa besar penyusutan yang terjadi dalam setiap proses pengolahannya.

Nilai tambah diperoleh melalui pengurangan nilai output dengan sumbangan input lain dan harga bahan baku. Dari semua proses pengolahan, ternyata kopi yang telah disangrai (roasted bean) yang memiliki nilai tambah terbesar, yaitu Rp 54.734,- pada kopi robusta dan Rp 94.361,- pada kopi arabika. Dengan demikian petani akan dapat memaksimalkan keuntungannya apabila menjual biji kopi kualitas baik pada level produk roasted bean dan mengolah biji kopi yang cacat hingga menjadi bubuk kopi. Melalui pengembangan agroindustri kopi, nilai tambah produk akan dapat memberikan keuntungan yang lebih besar kepada petani serta memudahkan penyediaan bahan baku bagi industri kopi skala kecil dan menengah. 
Tabel 5. Perbandingan nilai tambah dan keuntungan produk olahan buah kopi robusta dan arabika

\begin{tabular}{llrrrr}
\hline No. & Produk Olahan & $\begin{array}{c}\text { Nilai } \\
\text { Tambah } \\
(\mathrm{Rp} / \mathrm{kg})\end{array}$ & $\begin{array}{c}\text { Rasio Nilai } \\
\text { Tambah } \\
(\%)\end{array}$ & $\begin{array}{c}\text { Keuntungan } \\
(\mathrm{Rp} / \mathrm{kg})\end{array}$ & $\begin{array}{c}\text { Rasio } \\
\text { Keuntungan } \\
(\%)\end{array}$ \\
\hline 1 & Green Bean Robusta & 4.362 & 43,62 & 3.181 & 31,81 \\
2 & Green Bean Arabika & 17.862 & 71,45 & 16.681 & 66,73 \\
3 & Roasted Bean Robusta & 54.734 & 54,73 & 52.623 & 52,62 \\
4 & Roasted Bean Arabika & 94.361 & 47,18 & 91.833 & 45,92 \\
5 & Bubuk Kopi Robusta & 13.259 & 8,84 & 9.925 & 6,62 \\
6 & Bubuk Kopi Arabika & 38.171 & 12,72 & 34.421 & 11,47 \\
\hline
\end{tabular}

\section{Selecting and Grading Produk Olahan Kopi}

Nilai tambah suatu produk akan dapat meningkat secara lebih optimal apabila produk mendapatkan nilai jual yang tepat sesuai dengan kualitasnya. Untuk itu sangat diperlukan adanya pengetahuan mengenai selecting and grading dalam pengolahan kopi. Selama ini Kelompok Sari Tani hanya menyeleksi kopinya menjadi 2 bagian, yaitu kopi kualitas baik dan kopi cacat. Semua kopi yang telah diseleksi tersebut tetap diolah hingga akhir, yang membedakan hanya pada pemasarannya. Kopi yang berkualitas baik akan dijual kepada konsumen sementara kopi yang cacat hanya dijadikan sebagai konsumsi pribadi.

Menurut ketua umum Specialty Coffee Associations of Indonesia, A. Syafrudin, secara umum kopi dibagi menjadi tiga kategori yaitu specialty, premium, dan komersil. Kopi specialty mempunyai nilai cupping score di atas 80, kopi premium memiliki nilai cupping score di bawah kopi specialty yaitu 70 hingga 80 , sedangkan kopi komersil memiliki nilai cupping score di bawah 70 . Kopi yang telah masuk ke kelas specialty akan memiliki harga yang jauh lebih mahal dan biasanya kedai-kedai kopi yang memburu kopi kualitas ini. Kopi berkualitas premium umumnya saat ini dijual langsung kepada konsumen, namun tak jarang kedai kopi juga masih membeli kopi kualitas ini apabila kopi kualitas specialty sedang tidak tersedia di pasaran. Sementara kopi komersil (asalan) biasanya digunakan oleh pabrik-pabrik untuk dijadikan kopi instan karena harganya yang masih terjangkau dan pengolahannya yang tidak murni kopi, melainkan terdapat bahan tambahan lainnya. Apabila dibandingkan harga jual kopi dari setiap kualitas memiliki selisih besaran yang cukup signifikan, Tabel 6 menyajikan data harga berbagai kualitas kopi yang berasal dari Pulau Jawa.

Berdasarkan informasi harga yang tersaji pada Tabel 6, dapat diketahui jika petani melakukan proses selecting and grading secara lebih cermat maka produknya akan 
dapat memiliki nilai jual yang lebih tinggi,

terutama pada kualitas specialty.

Tabel 6. Perbandingan harga green bean dan roasted bean kopi di lapang dengan harga rata-rata pasaran

\begin{tabular}{rlrrrr}
\hline Jenis & \multirow{2}{*}{ Kopi } & Bentuk Olahan & $\begin{array}{c}\text { Harga di Lapang } \\
(\mathrm{Rp} / \mathrm{kg})\end{array}$ & \multicolumn{3}{c}{ Harga Rata-Rata Pasar $^{\mathrm{b}}(\mathrm{Rp} / \mathrm{kg})$} \\
\cline { 4 - 6 } Robusta & Green Bean & 40.000 & 72.500 & 44.000 & 27.600 \\
& Roasted Bean & 125.000 & 212.000 & 140.000 & 95.000 \\
\hline \multirow{2}{*}{ Arabika } & Green Bean & 100.000 & 143.000 & 106.000 & 46.000 \\
& Roasted Bean & 250.000 & 369.600 & 261.000 & 175.000 \\
\hline
\end{tabular}

Jenis kopi khas di Jawa yang digunakan dalam penentuan harga rata-rata pasar yakni jenis kopi Java Preanger, Papandayan, Sumbing, Sindoro, Bowongso, Temanggung, Dampit Malang, Blawan Bondowoso, Ijen, dan Argopuro.

bData diperoleh dari situs jual beli online dan wawancara ke beberapa kedai kopi di Bogor dan Banjarnegara.

Kopi yang berkualitas specialty akan mengalami peningkatan harga mencapai $40-80 \%$ dari harga yang biasanya dijual di lokasi penelitian. Jika dikategorikan sebetulnya harga kopi yang selama ini dijual oleh petani Sari Tani termasuk ke dalam harga kopi kualitas premium. Oleh sebab itu guna mengoptimalkan keuntungan, kopi yang tidak termasuk ke dalam kategori kualitas specialty akan lebih baik jika diolah hingga menjadi produk bubuk kopi, mengingat harga bubuk kopi masih lebih besar dibandingkan harga roasted bean kualitas premium di pasaran, yakni sebesar Rp 150.000,- untuk kopi robusta dan sebesar Rp 300.000,- untuk kopi arabika.

Namun pada kenyataannya di pasaran, kedai-kedai kopi lebih menyukai untuk membeli produk olahan green bean dari para petani dibandingkan produk roasted bean. Kedai kopi tersebut memilih untuk menyangrai biji kopinya sendiri karena memiliki standar yang tinggi terhadap produk yang akan dijual kepada para penikmat kopi, sehingga tak jarang ditemukan kedai kopi yang sekaligus merangkap menjadi Roastery. Hanya sedikit kedai kopi yang membeli langsung olahan roasted bean langsung dari petani, terkecuali kedai kopi ini telah benar-benar menaruh kepercayaan terhadap petani akan produk roasted bean yang diolahnya.

Sebagian besar petani yang mengolah produknya hingga level roasted bean dan bubuk kopi lebih banyak menjualnya langsung kepada perorangan, terutama yang menjadi pelanggan setianya. Oleh sebab itu adanya edukasi tentang selecting and grading pada petani juga perlu diimbangi dengan pemberian informasi mengenai sasaran pemasaran yang tepat untuk setiap 
produknya, dimana green bean dijual langsung ke kedai-kedai kopi, sedangkan olahan roasted bean diutamakan untuk dijual langsung ke perorangan dan sebagiannya lagi ke kedai kopi, dan bubuk kopi dijual langsung ke konsumen (perorangan).

\section{REFERENSI}

Aklimawati, L., Soemarno, D., Mawardi, S. 2016. Application of marketing mix in home industry: focussed on micro and small scale coffee industry. Pelita Perkebunan. 32(1): $52-66$.

Gittinger, J.P. 2008. Analisa Ekonomi ProyekProyek Pertanian. Ed ke-2. Mangiri K, Sutomo S, penerjemah; Bhaktiyani $\mathrm{R}$, Ulfah S, editor. Jakarta (ID): Universitas Indonesia Press.

Hairiah, K., Utami, S.R., Verbist, B., Van Noordwijk, M., Sardjono, M.S.
2003. Prospek Penelitian dan Pengembangan Agroforestri di Indonesia. Bogor (ID): International Centre for Research in Agroforestry.

Hayami, Y., Kawagoe, T., Morooka, Y., Siregar, M. 1987. Agricultural Marketing and Processing in Unpland Java A Perspective From A Sunda Village. Bogor (ID): CGPRT Center.

Indonesia Power. 2018. Perkembangan Laju Sedimentasi Waduk Panglima Besar Soedirman dan Tingkat Erosi Daerah Aliran Sungainya. Banjarnegara (ID): Indonesia Power.

Nurmalina, R., Sarianti, T., Karyadi, A. 2010. Studi Kelayakan Bisnis. Departemen Agribisnis (ID): Institut Pertanian Bogor.

Sudjarmoko, B. 2013. Prospek pengembangan industrialisasi kopi Indonesia. STRINOV. 1(3): 99-110 